\title{
Multi-Dimensional Approach to Crisis Management in Theological Institutions
}

Ehisienmen Charles*

\begin{tabular}{|c|c|}
\hline he Nigerian Baptist Theological Semina & Ogbomoso, Nigeria \\
\hline $\begin{array}{c}\text { Article History } \\
\text { Received: } 02.09 .2020 \\
\text { Accepted: } 17.09 .2020 \\
\text { Published: } 30.092020 \\
\text { Journal homepage: } \\
\text { https://www.easpublisher.com/easjebm } \\
\end{array}$ & $\begin{array}{l}\text { Abstract: The title of this paper is multidimensional approach of crisis management in } \\
\text { the theological institution. This paper will examine the way and manner crisis is been } \\
\text { manage in theological schools. The theological institution, like every other society } \\
\text { encounters internal crises. This research will contribute to further learning on how crisis } \\
\text { is been managed in the Universities and other establishment in the society in including } \\
\text { religion and social sciences. This paper will portray the extent to which these approaches } \\
\text { can help ameliorate the issue of present crisis in the theological institution. Statement of } \\
\text { the problem: the way and manners crisis are handled in the theological institutions is } \\
\text { alarming due to biased nature of some leaders. Methodology: Due to essential nature of } \\
\text { this research work, the researcher will use primary, secondary and internet sources. } \\
\text { Keywords: Multi-Dimensional, Approach, Crisis Management, Theological, Institution. }\end{array}$ \\
\hline
\end{tabular}

\section{INTRODUCTION}

The issue of crisis cannot be overemphasized. We all experience crisis from the moment we are conceived until the day we die. Crisis is then an essential and normal part of our daily lives from home, school, office and in every part of human endeavors. Crisis enables us to face the problems of life if well handled, and it is not a license to ones end of life, it is like moving from usual to unusual. According to (Wesley 2002. 81) stated that crisis is seem as offering the possibility of change. The Chinese symbols for crisis is an amalgam of the symbols for danger and opportunity. Despite, that seminary is a training center for pastors that doesn't Immune her from crisis. In as much as people work together in that environment crisis become inevitable. This is to bring to the mind that seminary trainers are humans just like every other person.

According to (Sam 2011, 98) "crisis is part of life. It is a crucial time in human life. It may be defined as a turning point in human life. In other words, it is a decisive or critical moment in life". Crisis is part of everyday activities both at home and in office. (Sam 2011, 99-100) when crisis occurs, the person"s equilibrium is disturbed. Crisis is not always bad; it is just like stress at times. It may be turning point for better, and it can bring danger and upset. It can carry with it opportunity for growth and change. (Colliins2007, 746) agreed with the view above that crisis is a turning point that usually cannot be avoided. Crises may be expected or unexpected, real or imagined, actual (like the death of a love one) or potential (like the prospect that a love one will die soon). He further stated that crises are filled with danger because they disrupt life and threaten to overwhelm the people who are affected. According to (Good friday 2003, 110) Crisis in pastoral ministry are inevitable. But it is essential for a pastor to have wisdom and humility to seek assistance in handling these situations before serious damage is done. This research will address the issue of crisis management in the theological seminary. This research will enhance the leaders to resolve and manage crisis in any theological institutions in Nigeria through the intervention process.

\section{Causes of Crisis In Theological Institution}

Crisis does not occur without any issue bee it personal or corporate. For an Institution to experience crisis inter or extern the following would be consider as causative factors.

1. Emotional Imbalance: Any crisis that man is into emotional imbalance is a factor to be considered. Just as each of us has unique experience in life, each of us has unique emotional responses. No one emotional response is more valid than another. You 
may be frightened or perplexed or feel great joy or relief at what you read. Another person may have a very different response. According to (David J. Atkinson and David H. Field 1984, 341),

An emotion is an involuntary response of the personality to certain stimuli, either outside us or from within us, usually associated with bodily changed (in, for instance, facial expression, breathing, heartbeat, sweat), with more extreme feelings than usual, and sometimes with intense behavior of either aggression or flight..... Various factors probable contribute to the pattern of a pattern, e.g. parental modeling or early learning experiences. These often lead to cultural differences in the ways emotions are expressed.

Emotional imbalance cannot be out of man"s daily activities both within and outside, since man is to face the reality of life. This is capable of disturbing his/her daily relationship either with the family or place of work.

2. Finding someone on whom to lay blame: this is another cause of crisis both out home and office. When crisis occur who do you blame? Our automatic tendency is to seek someone on whom to lay the blame for our trouble. There are times when other people are at fault, at least to a degree, for the trouble we experience. But not all crises is cause by, or is even related to, specific individuals we can name. Most trouble is multifaceted; they nearly always involve more than one other person or one lone cause. Laying blames on individual without any just cost create can crisis in any organization.

3. Attitude of Pride: The Lord hates human pride. James 4:6 state very clearly, "God resist the proud, but gives grace to the humble. The leader that failed to recognized or respects his/her subject end up stirring crisis in the establishment. According to (David J. Atkinson and David H. Field 1984, 685), stated that pride (or hubris) is the inordinate desire to excel over others and God, often with malicious intent. (Charles F. Pfeiffer and Howard F. Vos, John Rea 1975,1393$)$ supported the view above that pride an attitude of self-exaltation which, in its conceit of superiority, arrogantly tramples on others and, in it independence of spirit, self-sufficiently rebels against God.

\section{Multi-Dimensional Approach the Bases for Crisis Intervention in Theological Institution Leadership in Institution Crisis}

(Myles 2005, 19) Leadership is a trusted privilege given by followers. There is nothing as elusive as leadership. All the money in the world can make you rich, and all the power in the world can make you strong, but these things can never make you a leader. You can inherit a fortune but never leadership. Yet there is no greater need in our twenty-first century world than effective, competent leadership. There have been many researches on managing church conflicts but all of them either focus on the causes or the use of the Bible in managing the conflicts.

While conflict is generally regarded as a disagreement through which the parties perceive a threat to their needs, interests or concerns, crisis is a higher level of conflict which is a step from breaking parties involved apart. (Krejcir 2014, 66928) points out that conflict are inevitable. We will come across various disagreements, misunderstandings, and distinctions with various views of moral and value stands with one another that will converge in our relationships. Church history shows that conflict occurred at various times and when it did the Church responded by reexamining and redefining its doctrines. Apart from doctrinal crises, members of local churches also encounter other types of crises. So it's critical for staff and key leaders to be ready for crisis before it happens. (Ken Newberger 2013,) Crisis should however not be romantised. While crisis is preventable, or could be managed, at times it could be mismanaged. But times of crisis can be opportunities for the institution to develop if it handles its challenges well. Conflict can escalate to crisis." The first stage is when interpersonal relationship within the particular Christian society is preceded with uncomfortable feeling among members. At this stage, conflict potential only exists but needs the right condition for it to explode. Next is the stage when an identifiable problem emerges and the focus is already on it. Here as they discuss the problem. The participants are civil and respectful to one another as they each share their perspective. As the focus of conversation changes from what should be done and what is the best solution, to a debate of who is right and who is wrong, frustration sets in because the attempt to achieve one,s goals is undermined by another. At this stage, parties need to be more cautious the way they deal with each other. If the matter is not resolved, then collaboration wanes except with those who take their respective sides. When parties now see themselves as adversaries and antagonists they start to attack members of the other group verbally. Once conflict has escalated in intensity to a certain level, direct discussion among parties involved has little usefulness. At this stage a neutral peacemaker is needed to resolve the differences.

Leadership is actively involved in desensitization. In conflict management however, leadership should not be employed to dominate but reassure everyone involved in the conflict that the encounter is normal in human relationship, and that the institution is not immune to conflict. In deliberation, the leader/leadership team needs to consider the points of view of various people. (Richard n.p,)Contemporary Evangelicals are fairly accused of uncritically importing leadership models from the corporate business world or from secular systems of administration because 
Christian leadership is not authority-driven (cf. Mark 10:35-45). This criticism should however be taken with caution because both Christians and non-Christians benefit from general revelation through which God reveals certain truths to the whole humanity. (St. Augustine n,d) rightly observes: let every good and true Christian understand that wherever truth may be found, it belongs to its master, and while he recognizes and acknowledges the truth even in their religious literature, let him reject the figments of superstition" (Bilezikian, 2007, 6). But Christian leadership has certain distinguishing features which include the presence of a gift of the Holy Spirit (Rom 12:8); and reliance on instruction, exhortation, and persuasion to fulfill its mandate". (James means 2003 106) Leadership style relates to the use of power, authority, or influence in the decision- making process of boards, committees, or congregations. Each pastoral leader must develop a flexible leadership style that grows out of scriptural interpretation, personality, ecclesiastical tradition, personal convictions and sensitivity to one ${ }^{e c}$ s conscience.

\section{Distinctive Of Theological Institutions Leadership \\ A Christian Leader IS A Christian: (Aubrey}

Malphurs 2003, 15) "At the very core of the Christian leader"s life is his or her personal conversion. To be a Christian leader, one must first be a Christian. This is the starting place of all Christian leader and leadership". For any Christian leader to be in leadership position he or she must experience to grow and continual growth is a key to effective leadership. "Consequently they"ve place their trust in Christ, the God-man who died to pay for their sins (2 Cor. 5:21). This means that now they are authentic Christians. They"ve been born again in the sense that they"ve experienced a spiritual birth in addition to their natural birth (John 3:1-21)" (15).

A Christian Leader Is Honest. (LeRoy Eims 1996, 13) "Leader should accept responsibility to keep everything open and above-board. Over the years on the international scene, we have seen giant corporations taken task for bribery. We see the same problems o the national level, as sins of leaders are exposed." The first ingredient for building leadership credibility is character. Godly character is the foundation of Christian leadership, the essential qualifying element. Because it earn people ${ }^{e e}$ s respect and, most importantly, produces trust, character is the most crucial factor in all relationship.

\section{A Christian Leader listens to Criticism:} (LeRoy Eims 1996, 13) Leaders should accept responsibility to listen to criticism from the ranks. Whoever heeds correction shows prudence (prov. 15:5), but $\mathrm{He}$ who hates correction will die (prov. 15:10). There is hope for people who take their medicine." (Kouzes Posner 2004, 34) Successful leaders have high expectations, both of themselves and of their constituents. These expectations are powerful because they are the frames into which people fit reality. Criticism helps leaders to attend wonderful success in their leadership position.

\section{Resolving Terminological Crisis}

(Andrews 2014 n,p)University defines Christian leadership as $-\ldots$ a dynamic relational process in which people, under the influence of the Holy Spirit, partner to achieve a common goal". This definition of Christian leadership is persuasive to the present writers and is adopted for this work. Dominance, superiority, command, and control are not foreign to Christian leadership. The theological institution is characterized with both human and spiritual attributes. Theological management therefore involves blending the spiritual and the human in the ecclesia (church). It is in the human relational aspect that social sciences and humanities hold the prospect of collaborating with the institution in the search for managing its crisis. In a way, conflict is a disagreement through which the parties involved perceive a threat to their needs, interests or concerns. This definition raises four important issues: It is a disagreement; parties are involved; threat is perceived; and needs, interests, or concerns are involved. (Larry L. McSwain \& William C. Treadwell, 1981, n,p) (http://iabmp.org/conflictmanagement-psychology-and-science/, 2015) Similar issues have led some others to view conflict as exclusively implying the imagination of painful memories of arguments, hurt feelings, violence, and hatred". But conflict does not need to always be so". The more important thing is not the conflict itself but what is done with it. (Pearce http://www.ehow.com/info, 2014 n,p) differentiates disagreement from conflict thus: When you disagree with someone, you have a difference of opinion because you and the other person have different interests, values, needs and intentions. Disagreeing with someone isn't a bad thing. It can be viewed as positive and functional as well as natural. (Cindi Pearce, http://www.ehow.com/info) Disagreement doesn't have to lead to a huge fight. Conflict, on the other hand, is a powerful collision or dispute of needs, values, interests and intentions between two individuals or communities, groups, nations and organizations". Conflict is generally considered unhealthy competition which includes distrust, hostility, lack or loss of affinity and suspicion. Conflict happens when needs are not met or when a group or a person is seen as obstructing the goals of another group or person. But while its outcome is often negative, it can sometimes be constructive, lead to purposeful disagreement and even result in positive outcomes and better decision making. So the way conflict is managed in the theological institution is very important.

\section{Incorporating Vision into Theological Management of Crisis}

(Awojobi,,s2003, 43) interpretation of visionary leadership is different from the one adopted in 
this article. He links it loosely with transformational leadership. (Myles 2005, 54) Leadership is the capacity to influence others through Inspiration motivated by a passion, generated by a vision, produced by a conviction, ignited by a purpose. (Myles 2005, 56) This conviction generates a vision in the person's heart that stirs a passion. The force of this person's passionate pursuit of the vision inspires others, who are stirred to join in and cooperate with the vision. This ultimate effect is called "influence" and results in the followers acknowledging the individual as their "leader." (Myles 2005, 61) Their passion inspired and influenced others who personally embraced the leaders' purposes and allowed these leaders to guide them in the specific direction of their visions, which brought about changes in the world. When fellow-workers are threatened with fear, intimidation, and physical attack, the steadfastness and belief to hold their God-given purpose inspired vision will not be completed. (Awojobi,,s2003 43-44) further raises the following vital points for visionary leadership in times of crisis. First is that it is good to write down one,,s vision. Such removes doubt, reveals desires, exposes potential conflicts with the vision, and makes one accountable the way he/she acts. (Casey 1971, 31) A vision is a mental picture of a future state. Your vision must be a purpose a purpose for life strong enough to motivate you to action. Your vision must be the purpose for your existence. (Awojobi,,s2003 43-44) Second is that the leader,s vision should be communicated effectively through a clear and captivating presentation of the vision to members, repeated presentation of the vision, and evaluation of the communication efforts. And third, the leader should build support for the vision. These assume that the pastor,s vision agrees with his church,s vision otherwise, conflict of vision is an invitation to conflict of interest and purpose. In its effort to deal with conflict in the church, it is necessary the church continues to develop and maintain a sufficient number of crisis, managers (Cf. Mat 9:37-38). Reasons for this are multiple. There are various issues that call for attention in the church. As the church grows, so is the tendency for misunderstanding, increase in conflict, and rise in other potential threats to its oneness. Old age is making the replacement of some already serving in conflict management positions necessary. New challenges are arising for individuals and family members in the church and so the known approaches to crisis management would need to be reevaluated. The goals, purposes, or emphases of the church may need to be changed and changes in crisis management would need to reflect these.

\section{CONCLUSION}

As good as servant-leadership is for Christianity (Cf. John 13:2-15) it is always an overstatement to say that it is the only acceptable leadership style, and that it is right in all situations. In crisis management the combination of approaches would work better than a single approach. Better still, the method that works in a particular situation may not work in another situation due to differences in the factors involved. Sensitivity and flexibility are necessary watchwords while dealing with crisis situations between and among staff members.

It is also committed to helping members individually develop their relationship with God and with one another. All these make life-giving leadership relevant to the problem of conflict and crisis which may be destructive to the institutions of God. The contention of this article is that the theological institutions will be more effective in dealing with crisis within if the appropriates insights from other disciplines where they do not conflict with the Bible. The institutions will do well to complement whatever other conflict management methods it uses for prolonged crisis within the approach to reduce the subjective factors promoting it. Education in God,,s word and solicitation for God,s help in prayer cannot be divorced from any Christian solution to crisis.

\section{ReFERENCE}

1. Aubrey Malphurs. (2003). Being leaders; the nature of authentic Christian leadership. Published by Baker.

2. Casey Treat. (1971). church management; leading people in church growth. Seattle Washington.

3. Cindi Pearce. (2014). - Differences between a Conflict and a Disagreement, How, University of Liverpool, (n.d.), from http://www.ehow.com/info_8218226_differenc es-between- conflict-disagreement.html, accessed 24 March 2014, n.p.

4. Defining Christian Leadership, Christian Leadership Center. (2014). Andrews University, (n.d.), from http://old.andrews.edu/clc/christianleadership.html, accessed 21 March 2014, n.p.

5. Gary R. Collins. (2007) Christian counseling: A Comprehensive Guide Nashville Dallas Mexico City Rio De Janeiro Beijing

6. Gilbert Bilezikian. (2007). —Church Leadership that Kills Community, Priscilla Papers 21, 4- 6.

7. Goodfriday N. Aghawenu. (2003). Ministerial Ethics: A Devotion Ethics For Pastors and Christian Leader Mongraphics LTD. Publication.

8. James E. Means. (1993). Effective Pastors for a new century: helping leaders strategize for success; Baker Books.

9. Ken Newberger. (2014). Institute of Reconciliation and Peacemaker Training (2013), from. http://www.resolvechurchconflict.com/the stages of_unresolved_chu rch_conflict.html, accessed 23 March 2014, n.p.

10. Kouzes Posner. (2004). Christian Reflections on Leadership the Challenge; tossey-Bass A Wiley imprint. 
11. Larry, L., McSwain, \& William, C. Treadwell. (1981). - Preface, Conflict Ministry in the Church (Nashville: Broadman), n.p.

12. LeRoy Eims. (1996). Be A Motivational leader lasting leaderaship principles; published in United State by Victor.

13. New Dictionary of Christain Ethics and Pastoral theology. (1984). Edited by David J. Atkinson and David H. Field. InterVarsity Prees Downers Grove, Illinois, USA Leicester, England.

14. Peter O. Awojobi. (2003). Church Management (Ilorin: Kingdom, 2003), 43-44.

Myles Munroe Spirit of Leadership Cultivating Attributes that Influence Human Action. Publish by Whitaker House 2005
15. Peters, K. L. (2010). Conflict Management in the Christian Church. A research paper presented to the Faculty, Adler Graduate School, Richfield, Minnesota, for the degree of MA in Counselling and Psychology.

16. Richard D. Dobbins. (2014). —Managing Church Conflict Creatively, (n.d.), from http://ag.org/top/church_workers/intper_gen_confli ctmang.cfm, accessed 23 March 2014, n.p.

17. Sam .O Oyedele, (2011). Principles and Practices of Pastoral Care and Counseling; Resources for Effective Pastoral Ministry.By Amazing Publication.

18. Wesley carr. (2002). the New Dictionary of Pastoral studies, William publisher company Grand Rapids Michigan. 